\title{
MicroRNA-223 Acts as an Important Regulator to Kupffer Cells Activation at the Early Stage of Con A-Induced Acute Liver Failure via AIM2 Signaling Pathway
}

\author{
Fan Yanga,b Guohua Lou ${ }^{a, b}$ Xiaotang Zhou ${ }^{a, b}$ Min Zhenga Jiliang He ${ }^{c}$ Zhi Chen ${ }^{a, b}$ \\ aState Key Laboratory of Infectious Diseases Diagnosis and Treatment, First Affiliated Hospital, School \\ of Medicine, Zhejiang University, ${ }^{b}$ Collaborative Innovation Center of Infectious Diseases Diagnosis and \\ Treatment, Hangzhou, Institute of Environmental Medicine, School of Medicine, Zhejiang University, \\ Hangzhou, PR China
}

\section{Key Words}

Acute liver failure $\cdot$ AIM2 $\bullet$ IL-1 $\beta \cdot$ Kupffer cells $\bullet$ microRNA-223

\begin{abstract}
Background: Acute liver failure (ALF), known as a rapid and severe clinical syndrome, can induce multiple organ dysfunction and failure. It was noticed that Kupffer cells activation at the initial phase was involved in some intense inflammatory responses in the pathogenesis of ALF. However, detailed regulation mechanism of Kupffer cells activation during ALF is still obscured. Present study aimed to discover the potential regulator and explore deeper information of Kupffer cells activation at the early stage of ALF. Methods: The mouse model of ALF was established by Concanavalin A injection. Dynamic immunological statuses of Kupffer cells at the early stage of ALF were exhibited by detecting typical cytokines. The expression of inflammasome AIM2 was measured in both RNA and protein level. Its role of affecting Kupffer cells activation during ALF by inducing IL- $1 \beta$ production was identified by RNA interference in vitro. Moreover, the expression of miR-223 in vivo was measured by q-PCR and its role in regulating Kupffer cells activation during Con A induced ALF was determined by RNAs transfection. Results: Present study showed that mass production of IL-1 $\beta$ from isolated Kupffer cells in Con A treated mice might be the main driving force of Kupffer cells proinflammatory activation during ALF. The role of AIM2 in affecting pro-inflammatory activation of Kupffer cells by inducing IL-1 $\beta$ production was crucial to ALF. Further study found that miR-223 acted as a regulator in Kupffer cells activation at the early stage of ALF by influencing IL-1 $\beta$ production via AIM2 pathway. Conclusion: For the first time, this paper demonstrated that miR-223 acted to inhibit IL-1 $\beta$ production via AIM2 pathway, suppressing Kupffer cells pro-inflammatory activation at the early stage of ALF. Thus, it played an important role in the pathogenesis of ALF.
\end{abstract}




\section{Introduction}

Acute liver failure (ALF) is a rapid and severe clinical syndrome characterized by activation of intense inflammatory responses and huge amounts of hepatocyte death resulting in multiple organ dysfunction and failure $[1,2]$. Previous studies supported that activation of innate immune response played an important role in the complicated pathogenesis of ALF $[3,4]$. Kupffer cell, a special macrophage resided in the liver, is known as the crucial element in liver innate immune system and it is also involved in the development of liver inflammation during various liver diseases [5-7]. Our previous study had shown dynamic information of Kupffer cell functional status in the early stage of Concanavalin A (Con A) induced ALF. In the initial observation, there was a pair of contrary immunologic statuses of Kupffer cells in the early stage of ALF: pro and anti-inflamatory. The transition in between might affect the development of ALF eventually [8]. However, the detailed mechanisms of relationship between activated Kupffer cells and the early stage of ALF are still obscured.

Commonly, macrophages are turned into classic (M1) or alternative (M2) activation by different types of stimuli. M1 macrophages are thought as the pro-inflammatory regulator and it produces pro-inflammatory cytokines, such as TNF- $\alpha$ and IL-1 $\beta$. On the contrary, M2 macrophages are always related to the anti-inflammatory response [8]. In our previous report, we only focused on the changing levels of typical pro-inflammatory factor TNF- $\alpha$ and IL- 6 in Kupffer cells, left IL-1 $\beta$ uncovered [9]. IL-1 $\beta$, known as another critical pro-inflammatory cytokine, is mainly secreted from Kupffer cells during liver injury [10]. An increasing number of studies demonstrated that neutralization of IL-1 $\beta$ might effectively reduce the severity of many diseases, like type 2 diabetes and heart failure [11]. It was proved that secretion of IL-1 $\beta$ happened due to appearance of inflammasomes, which activate caspase- 1 and lead to production of both IL-1 $\beta$ and IL-18 $[12,13]$. Inflammasomes, a group of protein complexes such as NLRPs and AIM2, can activate caspase- 1 after being stimulated. Then Caspase- 1 will cleave pro-IL-1 $\beta$ into its mature form, and ultimately lead to the secretion of IL-1 $\beta$ [14]. AIM2 (absent in melanoma 2), one of typical inflammasomes, can be activated by dsDNA from bactria, virus or sometimes the host. Thus, AIM2 is also treated as one of the cytosolic DNA sensors [15]. Previous study found that AIM2 was prominently expressed in Kupffer cells in many animal models of hepatitis [16]. Recently Wu's group indicated that there might be a relationship between AIM2 expression in peripheral blood mononuclear cells and human with acute and chronic hepatitis B. They demonstrated that expression of AIM2 in acute hepatitis B was higher than that of chronic hepatitis B [17]. HBV is one of the most important factors that contribute to ALF. Therefore, these data may support the possibility that AIM2 expression in monocytes/macrophages can be associated with the pathogenesis of ALF. However, the detailed function of AIM2 in ALF is still obscured.

MicroRNAs are short-chain (about 22 nucleotides), non-coding RNA molecules that regulate gene expression in the level of transcription and post-transcription [18]. Their functions in different biological phenomena have been detected, including cell proliferation, development and death [19]. Previous studies indicated that some microRNAs played a crucial role in development of inflammation in macrophages [20-22]. There is increasing evidence indicating that miR-223 is an important regulator involved in various diseases, especially in inflammation [23]. Recent report showed that miR-223 was thought as the regulator of NF- $\kappa \mathrm{B}$ pathway by targeting IKK- $\alpha$ into macrophage differentiation during certain pro-inflammatory stimuli [24]. Other groups showed that miR-223 was also a novel regulator for macrophage polarization in obesity associated adipose tissue inflammation, by targeting Pknox1 [25]. It was also found that miR-223 might affect the production of IL$1 \beta$ via NF- $\kappa$ B signaling pathway [26]. Lately, a paper supported that miR-223 can influence IL-1 $\beta$ production by targeting classic inflammasome NLRP3 during LPS stimuli [27]. These results support that miR-223 is an important regulator in macrophage during different inflammatory responses. Our initial observation demonstrated that both pro- and antiinflammatory status of Kupffer cell existed in the early stage of ALF. The different dynamic immunologic statuses of Kupffer cell might influence the development of ALF [9]. However, 
whether certain important regulator like miR-223 is involved in this process and the detailed mechanism of regulation is undiscovered.

In this study, we aimed to explore the role of IL-1 $\beta$ and AIM2 in Kupffer cell in the early stage of ALF by using Concanvalin A (Con A) induced mouse model. Also, we target to find out whether miR-223 is involved in the process and the detailed mechanism of its crucial regulation function in ALF.

\section{Materials and Methods}

Mice and reagents

C57BL/6 mice (5-6 weeks old, male) were purchased from Experimental Animal Center of Chinese Science Academy (Shanghai, China). All mice were housed under pathogen-free conditions and performed under approval of the ethic committee from School of Medicine, Zhejiang University (Hangzhou, China) (ZJU201309-1-01-087). All experimental mice were randomized into three groups: $1 \mathrm{~h}, 3 \mathrm{~h}$ and $6 \mathrm{~h}$ after Con A $(20 \mathrm{mg} / \mathrm{kg}$ ) injection $(\mathrm{n}=5)$. Mice in control group were normal [28]. Concanavalin A (Con A) was purchased from Sigma Chemical Co (St. Louis, MI, USA). Con A was dissolved in phosphate-buffered saline (PBS). The solution was then intravenously injected into mouse tail vein at $20 \mathrm{mg} / \mathrm{kg}$. For in-vitro experiments, Kupffer cells were treated with $5 \mu \mathrm{g} / \mathrm{ml}$ Con A solution. RAW264.7 cells were obtained from the American Type Culture Collection. AIM2 small interfering RNA (siRNA) , miR-223 mimics, miR-223 inhibitor, (mimics and inhibitor are also siRNA) and relevant negative control were obtained from GenePharma (Shanghai, China). Monoclonal antibody anti- $\beta$-actin was obtained from Cell Signaling (Massachusetts, USA) and antiAIM2 was gained from Abcam (UK). Relative HRP-labeled secondary antibodies were obtained from Santa Cruz Biotechnology Inc (Santa Cruz, CA, USA). Anti-mouse F4/80 conjugated PE-Cy5 was purchased from eBioscience (San Diego, CA, USA).

\section{Cell isolation and culture}

Kupffer cells were isolated with collegenase IV and identified by F4/80 antibody as our previous paper described [9]. Firstly, mouse liver was perfused with D-Hank's solution via hepatic portal vein and then it was perfused again with $0.05 \%$ collagenase IV HBSS solution. Obtained liver tissue homogenate was filtered with 200-gauge mesh. The filtrate was then centrifuged for $5 \mathrm{~min}$ at $50 \mathrm{~g}$. Obtained supernatant was centrifuged again for 4 min at 500g. Obtained Pellet was then resuspended with $30 \%$ Percoll solution. The mixture was then added into $60 \%$ Percoll solution, and centrifuged for $20 \mathrm{~min}$ at $800 \mathrm{~g}$. Mid-layer with Kupffer cells were rinsed with DMEM, then transferred to culture plates. 6 hours after culturing, most Kupffer cells were in adherent state. The culture was then purified by rinsing with DMEM to eliminate non-adherent impurities. Purity of Kupffer cells was 90\%, quantified with PE-Cy5 marked F4/80 antibody. Purified Kupffer cells were identified with PE-Cy5 marked F4/80 antibody. 90\% purity was obtained. Cells were cultured in DMEM (Corning, NY, USA) containing 10\% FBS.

\section{Serum ALT and AST level detection}

Retro-orbital sinus blood samples from Con A treated mice were taken at different time points. Serum alanine aminotransferase (ALT) and aspartate aminotransferase (AST) levels were then detected by Automatic Chemical Analyzer 7600-100 (Hitachi, Ltd., Tokyo, Japan)

\section{RNAs transfection and RNA interference}

Isolated Kupffer cells from normal mice were seeded in 24 -well plates $\left(1 \times 10^{5} /\right.$ well $)$ and incubated overnight and transfected with RNAs at a concentration of 30nM, using Lipofectamine RNAiMAX Reagent (Invitrogen, NY, USA) according to the manufacture's protocol. To silencing AIM2 mRNA, AIM2-siRNA was transfected into isolated Kupffer cells as previous data applied [29].

\section{Histology}

Sections of $10 \%$ neutral-buffered formalin fixed livers from control and experimental group were embedded by paraffin and cut into slices. The slices were stained with hematoxylin-eosin and observed with microscope. 


\section{RNA isolation and real-time quantitative PCR}

Total RNA was extracted from isolated Kupffer cells with TRIzol (Invitrogen, Carlsbad, CA, USA). Relevant cDNA was synthesized with PrimeScript RT Reagent Kit (takara bio inc, Japan). For miRNA analysis, total microRNA was extracted from isolated Kupffer cells with mirVana miRNA Isolation Kit (Ambion by Life Technologies, USA) and reverse transcribed with PrimeScript RT Reagent Kit (Takara bio inc, Japan). Quantitative PCR primers of miR-223 and U6 were used from previous study and the relative expression level of miRNA was normalized by U6 expression [26]. Real time quantitative PCR was performed on a 7900HT Fast Real-Time PCR System (Applied Biosystems, Foster, CA, USA) by SYBR Premix Ex Taq $I$ kit (Takara bio inc, Japan). Detected molecules' primer sequences were exhibited as following: AIM2, 5'-ccacgaagtcccaaataacg-3' and 5'-cacctccattgtccctgttt-3'; IL-1 $\beta$, 5'- agagcatccagcttcaaatctc-3' and 5'cagttgtctaatgggaacgtca- $3^{\prime} ;$ TNF- $\alpha, 5^{\prime}$ - cctatgtctcagcctcttctcat- $3^{\prime}$ and $5^{\prime}$ - cacttggtggtttgctacga- $3^{\prime}$; Arginase 1 , 5 ' - gaatggaagagtcagtgtggtg- 3 ' and 5' - gttgtcaggggagtgttgatgt- 3 '; $\beta$-actin, 5'- aacagtccgcctagaagcac-3' and 5'cgttgacatccgtaaagacc-3'. Each assay was repeated three times and the relative expression of mRNA in each sample was normalized by the control gene ( $\beta$-actin) mRNA.

\section{Cytokine assay}

The level of IL-1 $\beta$ in primary cultured Kupffer cells' supernatant was measured with ELISA kit (RayBiotech, Norcross, GA, USA) following manufacturer's protocol. Absorbance was tested at 450nm with microtiterplate reader (BioRad, Hercules, CA, USA).

\section{Western blotting}

Total protein from isolated Kupffer cells was extracted as previous described by Li et al. [30]. Protein quantification was performed with BCA Protein Assay kit (Thermo Fisher Scientific Inc, Rockford, USA). Prepared protein $(50 \mu \mathrm{g})$ was dissolved in $12 \%$ SDS-PAGE and then transferred to PVDF membranes (Millipore, Billerica, MA, USA). Afterwards, the membranes were incubated with relevant antibodies at $4^{\circ} \mathrm{C}$ overnight and later incubated with horseradish peroxidase conjugated secondary antibodies at room temperature for 2 hours. Visualized results were exhibited to X-ray film. The relative expression level of protein was normalized by the level of $\beta$-actin. Western quantitative analysis was performed with Image J.

\section{AIM2 3'-UTR luciferase reporter assay}

Fragments from mice AIM2 mRNA 3'-UTR with putative miR-223 binding sites were synthesized, and then ligated into the pGL3-REPORT vector (Promega, Shanghai, China). RAW264.7 cells were seeded in 24well plates $\left(1 \times 10^{5} /\right.$ well), incubated overnight and then co-transfected with AIM2 3'-UTR luciferase reporter plasmid (pGl3-AIM2 $80 \mathrm{ng}$ ) or empty vector and pRL-TK vector (Promega, Shanghai, China) along with miR-223 mimics or control (mimics or control final concentration,30nM). After 48 hours, firefly luciferase activities were measured by the Dual-Glo Luciferase assay system (Promega, Shanghai, China), following manufacturer's protocol. Relative luciferase activities were normalized to Renilla luciferase activity.

\section{Statistical analysis}

Experiments in present study were repeated three times. Results were showed as mean \pm SEM, analyzed by non parametric test or Student's t test using SPSS 16.0 for Windows. Statistical graphs were generated by Graphad Prism 5.0(Graphpad Prism version 5.0 software). $\mathrm{P}<0.05$ was considered as statistically significant.

\section{Results}

Characteristic of Con A induced Mouse ALF model

From Fig. 1a, the pathologic change in liver during early stage of ALF triggered by Con A was clearly observed. Only a small number of polymorphonuclear cells infiltrated at $1 \mathrm{~h}$, while necrotic foci were hardly seen. After $3 \mathrm{~h}$ exposure to Con A, scattered necrotic foci began to appear. Confluent necrotic foci were evidently emerged in the group of $6 \mathrm{~h}$. From Fig.1b and 1c, it was observed that ALT and AST levels in 6h group were evidently higher than $0 \mathrm{~h}, 1 \mathrm{~h}$ and $3 \mathrm{~h}$ groups. 


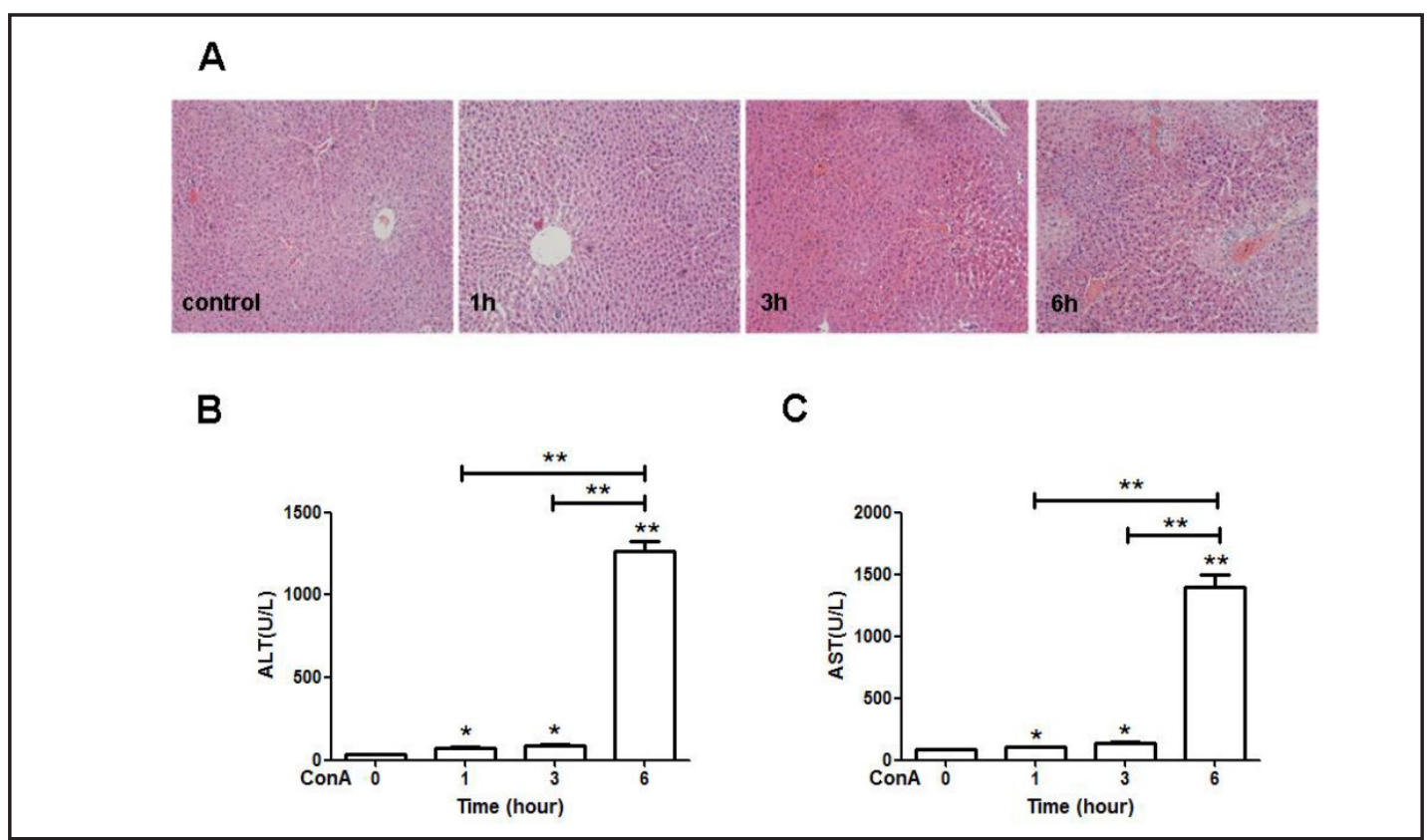

Fig. 1. Characteristic of Con A induced Mouse ALF Model. (A) Characterization of hepatic injury by histological analysis (H\&E staining). Images of liver sections from five mice in each group were exhibited (original images 400×). The ALT (B) and AST (C) levels in serum from mice treated with Con A for $1 \mathrm{~h}, 3 \mathrm{~h}$ and $6 \mathrm{~h}$. Data in each group $(n=5)$ were shown as mean \pm SEM. $\left({ }^{* *} p<0.01 ;{ }^{*} p<0.05\right.$; NS, not significant $)$.

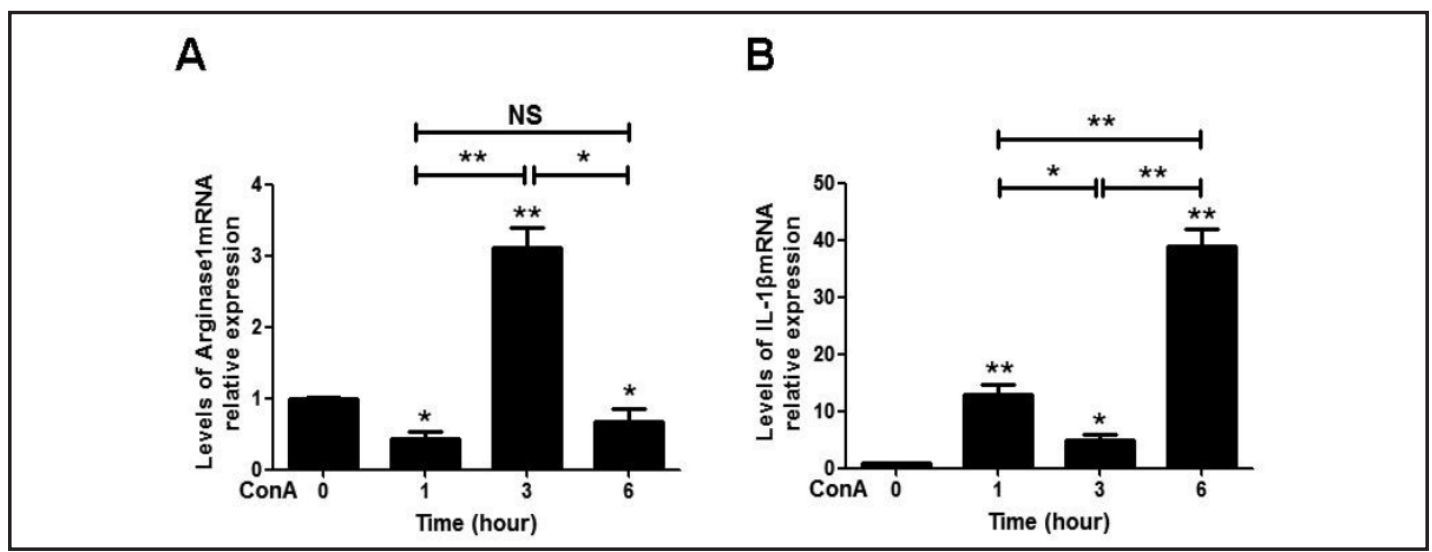

Fig. 2. Dynamic immunological status of Kupffer cells variation showed by representative markers in the early stage of ALF in vivo. Relative mRNA levels of Arg-1 (A) and IL-1ß (B) in Kupffer cells from mice stimulated with Con A for $1 \mathrm{~h}, 3 \mathrm{~h}$ and $6 \mathrm{~h}$ (qRT-PCR; normalized to $\beta$-actin). Data in each group (n=5) were shown as mean \pm SEM. $\left({ }^{* *} \mathrm{p}<0.01 ;{ }^{*} \mathrm{p}<0.05\right.$; NS, not significant $)$.

The dynamic immunologic status of Kupffer cells varied in the early stage of ALF induced by $\operatorname{Con} A$

We previously indicated that Kupffer cells played an important role in Con A induced ALF pathogenesis. Its dynamic properties in the early stage show pro-inflammatory activity at the very beginning, while the anti function start to take over as ALF went by [9].This scenario would be confirmed by the level change of typical marker for classic activation (M1) and alternative activation (M2). In previous research, we reported that expression level of TNF- $\alpha$, a classic M1-type marker, climbed up in $1 \mathrm{~h}$ after Con A stimulation, then gradually declined as time passed by [9]. In this article, we explored expression level change of M2- 


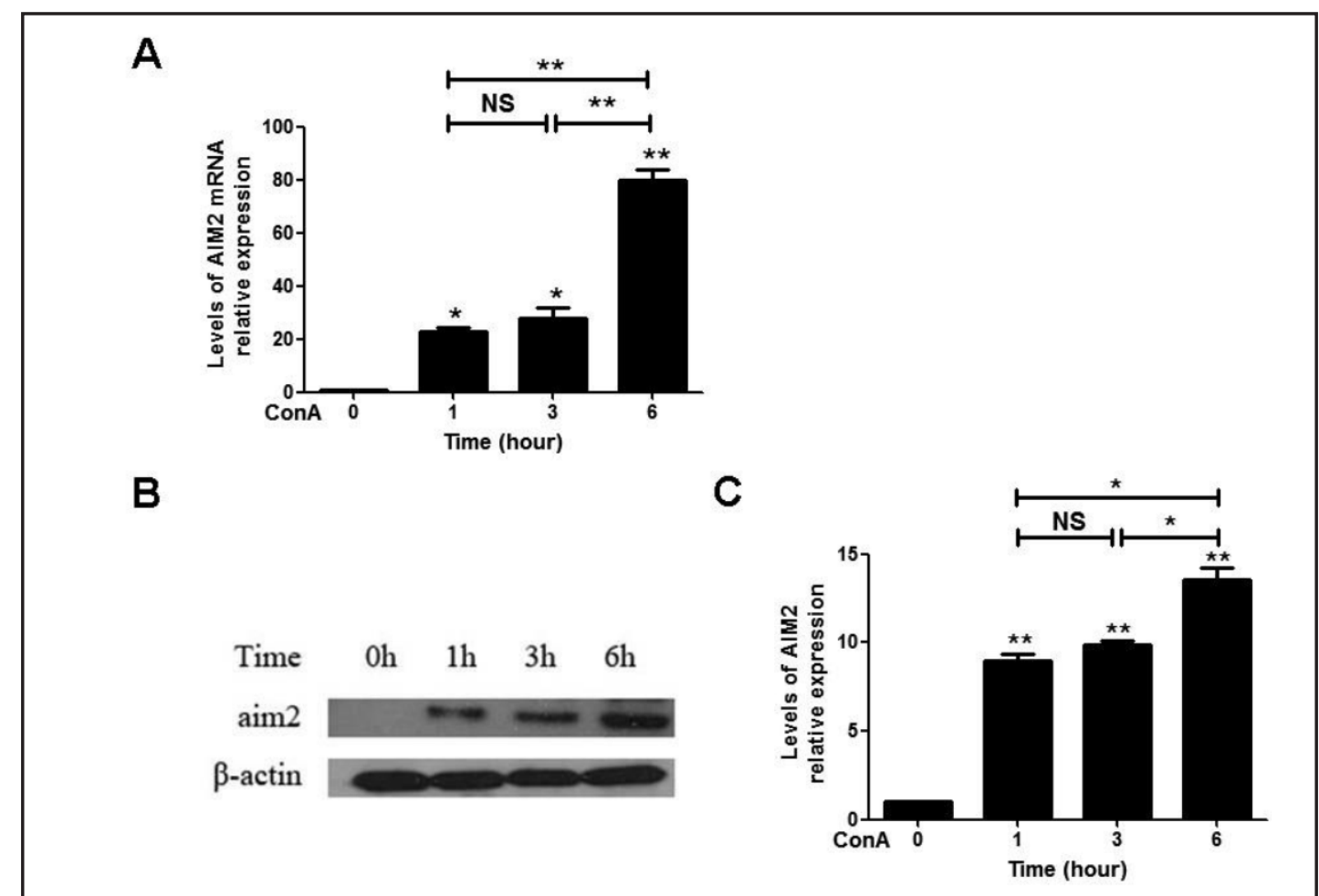

Fig. 3. The expression of AIM2 in Kupffer cells from Con A stimulated mice. (A) Relative mRNA levels of AIM2 in Kupffer cells from mice treated with Con A for $1 \mathrm{~h}, 3 \mathrm{~h}$ and $6 \mathrm{~h}$ (qRT-PCR; normalized to $\beta$-actin). (B) and (C) Protein levels of AIM2 in Kupffer cells from mice stimulated with Con A for 1h, 3h and 6h (Western blotting). (C) Relative quantification result from Western blotting. Data in each group $(n=5)$ were shown as mean \pm SEM. ${ }^{* *} \mathrm{p}<0.01 ;{ }^{*} \mathrm{p}<0.05$; NS, not significant $)$.

type marker Arg-1. Fig. 2a exhibited that Arg-1 expression level in isolated mice Kupffer cells rapidly decreased at $1 \mathrm{~h}$ after Con A injection. Then the expression evidently ascended in $3 \mathrm{~h}$ group, while it dropped back to $1 \mathrm{~h}$ level in the $6 \mathrm{~h}$ group. We also investigated another crucial factor in pro-inflammatory response to realize the dynamic change of Kupffer cells in ALF. The data from Fig. $2 \mathrm{~b}$ showed that change in IL-1 $\beta$ ascended evidently from control in $1 \mathrm{~h}$ group, while it dramatically decreased in $3 \mathrm{~h}$ group. The expression of IL- $1 \beta$ was dramatically higher in $6 \mathrm{~h}$ group, compared with the other two. This result might demonstrate that the immunologic status of Kupffer cells would still mainly be pro-inflammatory at the later stage of ALF due to mass production of IL-1 $\beta$.

The expression of AIM2 in Kupffer cells from Con A stimulated mice

To further explore the details of highly increased expression of IL-1 $\beta$, we detected the expression of potential trigger in isolated Kupffer cells during Con A induced ALF. Inflammasomes were known as essential components in signal pathway of producing IL$1 \beta$. The results in Fig. 3a showed that the mRNA expressing of inflammasome AIM2 in isolated Kupffer cells was obviously higher compared with normal group at $1 \mathrm{~h}$ after Con A injection. The expression level stayed stable from $1 \mathrm{~h}$ to $3 \mathrm{~h}$, aka some inhibition to further AIM2 expression existed during this period. After $6 \mathrm{~h}$ exposure, the mRNA expression of AIM2 dramatically increased, as compared with other groups. From Fig. 3b and 3c, it was observed that change of AIM2 protein level was similar to mRNA behavior curve. Protein level evidently increased at $1 \mathrm{~h}$ after Con A treatment. The level appeared stable from $1 \mathrm{~h}$ to $3 \mathrm{~h}$. In $6 \mathrm{~h}$ time, expression highly increased compared with previous groups. 
A

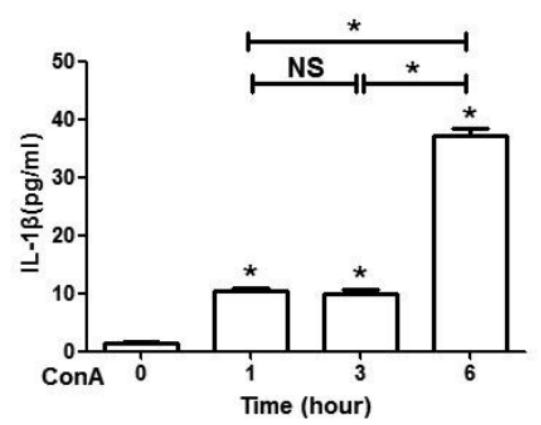

B

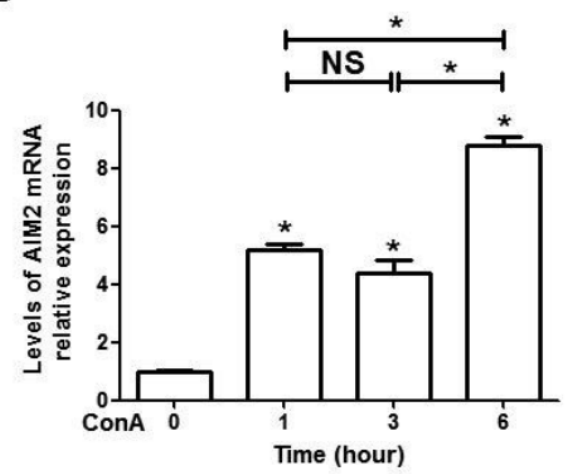

Fig. 4. The expression of IL-1 $\beta$ and AIM2 in Primary cultured Kupffer cells treated with Con A in vitro. Primary cultured Kupffer cells treated with Con A $(5 \mu \mathrm{g} / \mathrm{ml}$ ) for $1 \mathrm{~h}, 3 \mathrm{~h}$ and $6 \mathrm{~h}$. (A) Quantified protein level of IL-1 $\beta$ (ELISA). (B) Relative mRNA levels of AIM2 (measured by qRT-PCR; normalized to $\beta$-actin). Data from three independent experiments were shown as mean \pm SEM. $\left({ }^{* *} \mathrm{p}<0.01 ;{ }^{*} \mathrm{p}<0.05\right.$; NS, not significant).

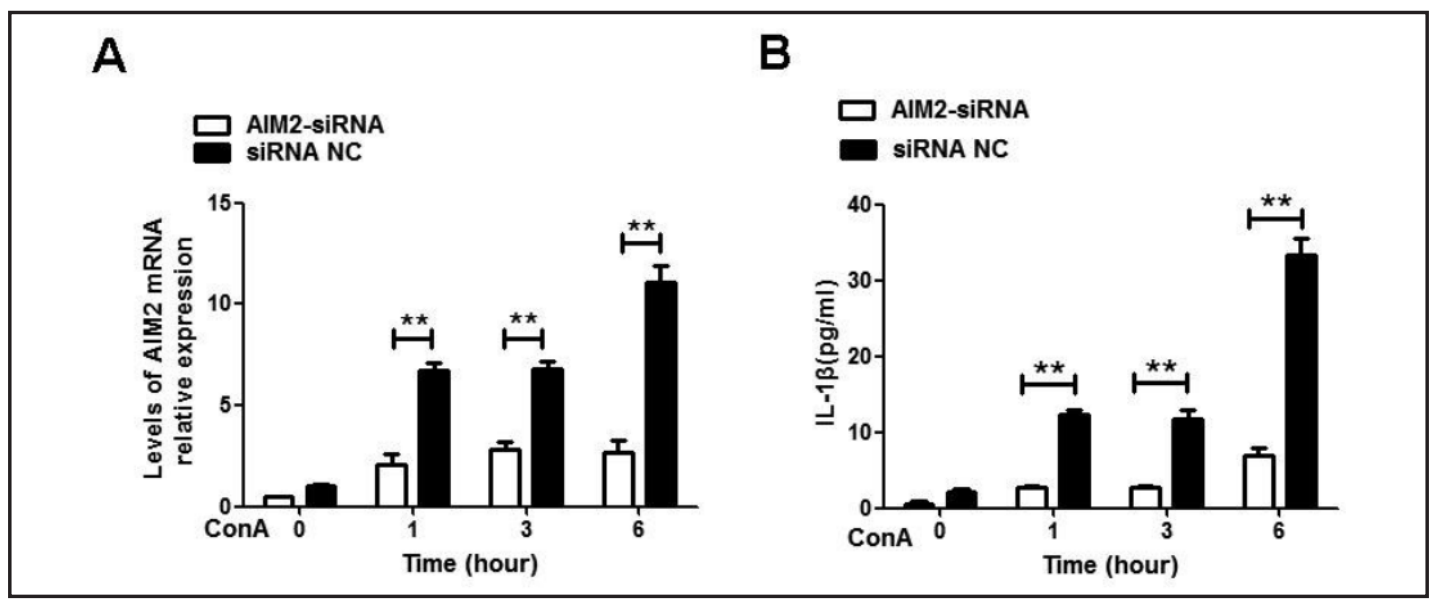

Fig. 5. AIM2 induced production of IL-1 $\beta$ in Kupffer cells in Con A induced ALF. Primary cultured Kupffer cells were transfected with AIM2-siRNA or siRNA control. 48 hours after transfection, cells were then exposed to Con $\mathrm{A}(5 \mu \mathrm{g} / \mathrm{ml})$ for $1 \mathrm{~h}, 3 \mathrm{~h}$ and $6 \mathrm{~h}$, with siRNA NC $0 \mathrm{~h}$ as control. (A) The mRNA level of AIM2 (qRT-PCR; normalized to $\beta$-actin). (B) Quantified protein level of IL-1 $\beta$ (ELISA). Data from three independent experiments were shown as mean \pm SEM. ( ${ }^{* *} \mathrm{p}<0.01$; ${ }^{*} \mathrm{p}<0.05$; NS, not significant).

The expression of IL-1 $\beta$ and AIM2 in Primary cultured Kupffer cells treated with Con A in vitro

For subsequent research purposes, we firstly build the in-vitro Con A cell model, and detect IL-1 $\beta$ and AIM2 expression levels from it. Similar results were observed as from in-vivo experiments. From Fig. $4 \mathrm{a}$, it was observed that IL-1 $\beta$ expression ascended in the beginning, then stabilized from $1 \mathrm{~h}$ to $3 \mathrm{~h}$, and climbed up again evidently from $3 \mathrm{~h}$ to $6 \mathrm{~h}$. Fig. $4 \mathrm{~b}$ exhibited change curve of AIM2 expression level as time passed on. Same behavior trend was observed as in IL-1 $\beta$.

AIM2 can induce IL-1 $\beta$ secretion in the pro-inflammatory response in Kupffer cells in Con A triggered $A L F$

From these results, we found that the change levels of AIM2 in Con A induced ALF model were almost the same as the IL-1 $\beta$ expression observed above. Therefore, we used siRNA to silencing mRNA expression of AIM2 (Fig. 5a), in order to detect further relationship between 


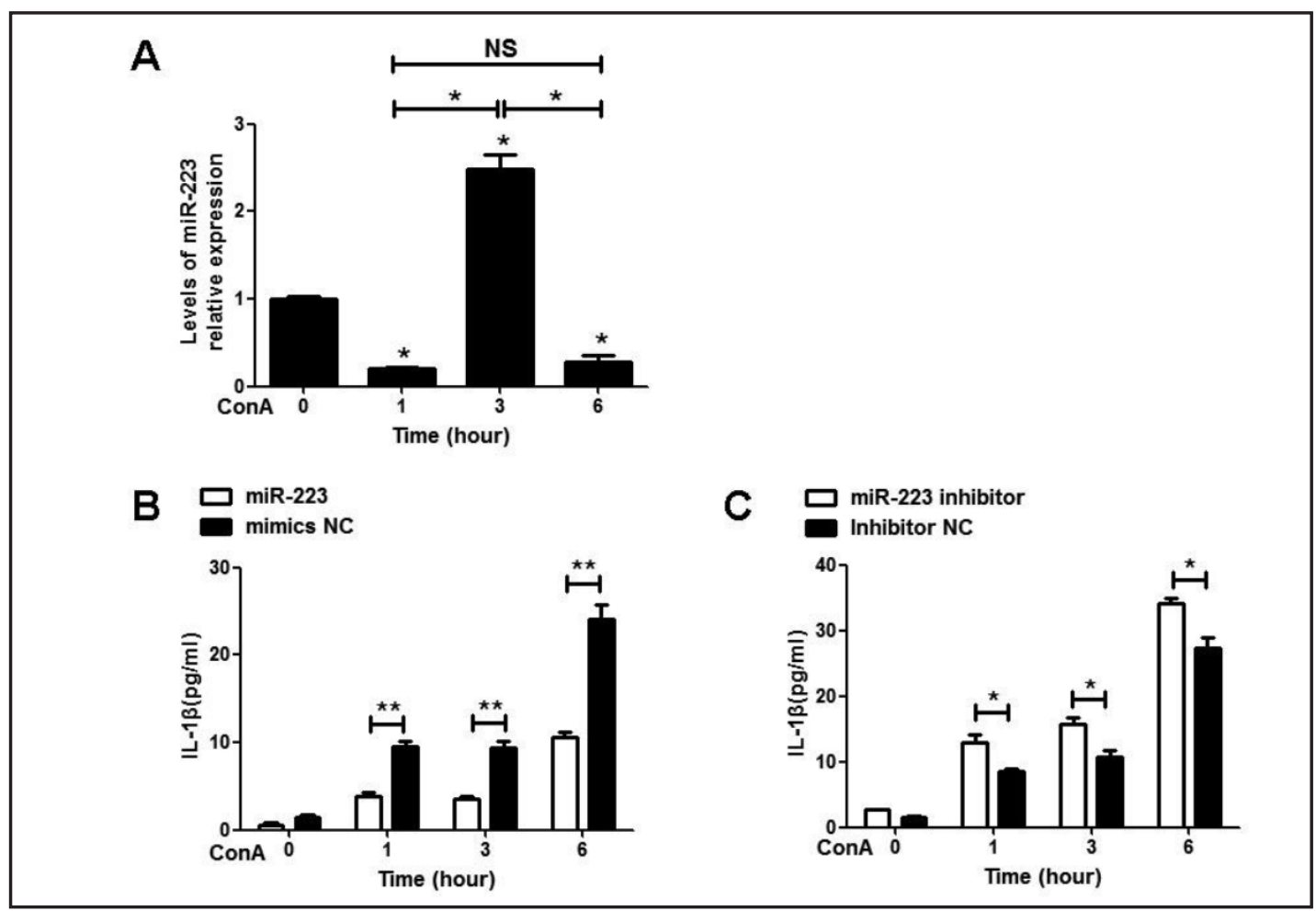

Fig. 6. MiR-223 inhibited IL-1 $\beta$ production in Kupffer cells in Con A induced ALF. (A) The expression of miR-223 in Kupffer cells from mice exposure to Con A for $1 \mathrm{~h}, 3 \mathrm{~h}$ and $6 \mathrm{~h}$ (qRT-PCR; normalized to U6). Data in each group $(n=5)$ were shown as mean \pm SEM. $\left({ }^{* *} p<0.01 ;{ }^{*} p<0.05\right.$; NS, not significant) Primary cultured Kupffer cells were transfected with miR-223 mimics, miR-223 inhibitor or relevant control. 24 hours after transfection, cells were exposed to Con A ( $5 \mu \mathrm{g} / \mathrm{ml})$ for $1 \mathrm{~h}, 3 \mathrm{~h}$ and $6 \mathrm{~h}$. (B) Quantified protein level of IL-1 $\beta$ (ELISA), with mimics NC $0 \mathrm{~h}$ as control. (C) Quantified protein level of IL-1 $\beta$ (ELISA), with inhibitor NC 0h as control. Data from three independent experiments were shown as mean \pm SEM. $\left({ }^{* *} \mathrm{p}<0.01 ;{ }^{*} \mathrm{p}<0.05\right.$; NS, not significant).

AIM2 and IL-1 $\beta$ in Kupffer cells in the early stage of ALF. In vitro, the level of IL- $1 \beta$ secretion in AIM2-siRNA pretreated group considerably declined compared with siRNA control group (Fig. 5b). The conclusion was drawn that AIM2 could induce the production of IL-1 $\beta$ in Kupffer cells in Con A stimulated ALF.

MiR-223 is involved in inflammatory response of Kupffer cells in the early stage of ALF by regulating the production of $I L-1 \beta$

Research showed that miR-223 could regulate the change of macrophage phenotype from M1 to M2 in inflammation process [25]. We detected the condition of miR-223 to identify whether miR-223 was potentially involved in Kupffer cells activation in Con A induced ALF. Fig. 6a showed that the expression of miR-223 in 1 h group decreased for more than $50 \%$, as compared with control group, while the expression significantly increased in $3 \mathrm{~h}$ group. After $6 \mathrm{~h}$ treated with Con A, the expression was also evidently declined compared with $3 \mathrm{~h}$ group. These results suggested that the expression level of miR-223 might be involved in inflammatory response in activated Kupffer cells in the early stage of ALF. We previously observed that pro-inflammatory properties of Kupffer cells were mainly related to the production of IL-1 $\beta$. Therefore, we performed the study in vitro to investigate the potential relationship between miR-223 and IL-1 $\beta$ in Con A induced ALF. We firstly transfected miR223 mimics and inhibitor into the primary cultured Kupffer cells, then treated them with Con A $(5 \mu \mathrm{g} / \mathrm{ml})$. After different exposure periods to Con A, cells were collected and subsequent 
A

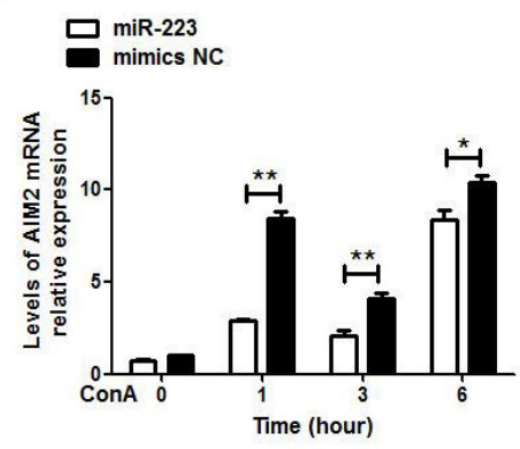

B

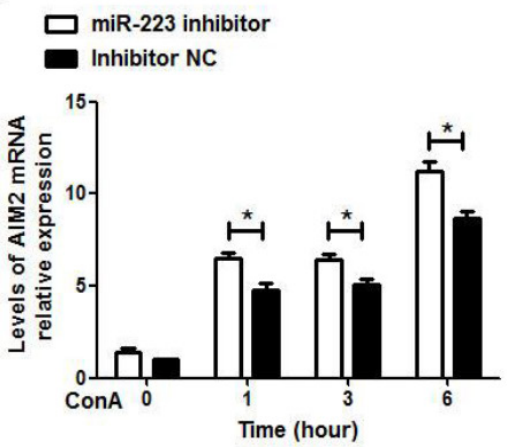

C $\operatorname{miR}-223$

NC

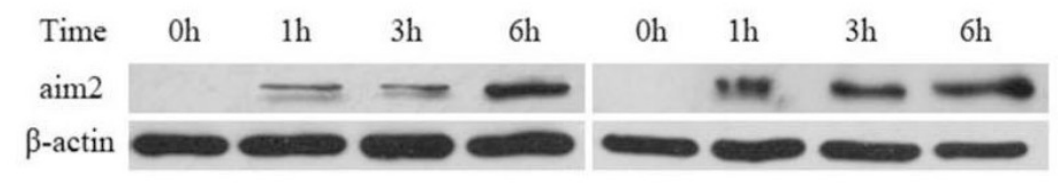

miR-223 inhibitor

Inhibitor NC

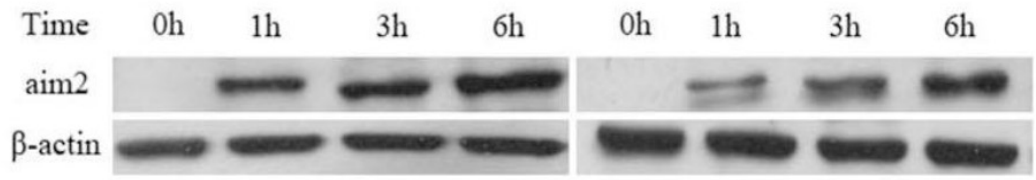

D

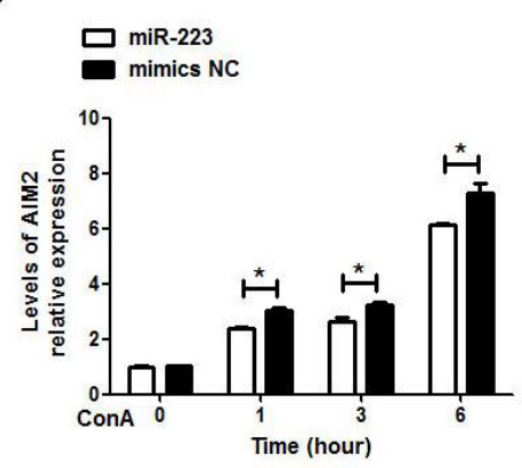

E

$$
\text { Inhibitor NC }
$$

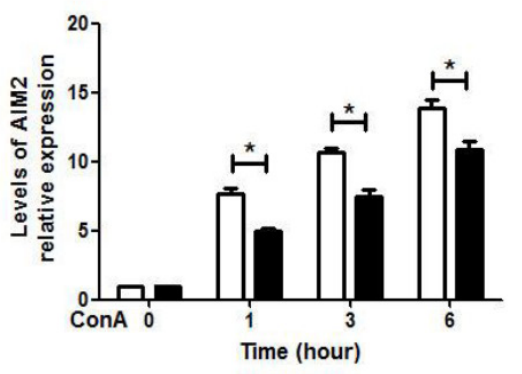

Fig. 7. MiR-223 negatively regulated AIM2 in Kupffer cells with Con A treatment. Primary cultured Kupffer cells were transfected with miR-223 mimics, miR-223 inhibitor or relevant control. After 24 hours, cells were exposed to Con A $(5 \mu \mathrm{g} / \mathrm{ml}$ ) for $1 \mathrm{~h}$, 3h and $6 \mathrm{~h}$. (A) The mRNA level of AIM2 (qRT-PCR; normalized to $\beta$-actin), with mimics NC $0 \mathrm{~h}$ as control. (B) The mRNA level of AIM2 (qRT-PCR; normalized to $\beta$-actin), with inhibitor NC $0 \mathrm{~h}$ as control. (C) The protein level of AIM2 (Western blotting). (D) Quantified protein level of AIM2 (Western Relative Quantification, normalized to $\beta$-actin), with mimics NC 0h as control. (E) Quantified protein level of AIM2 (Western Relative Quantification, normalized to $\beta$-actin), with inhibitor NC $0 \mathrm{~h}$ as control. Data from three independent experiments were shown as mean \pm SEM. $\left({ }^{* *} \mathrm{p}<0.01\right.$; ${ }^{*} \mathrm{p}<0.05$; NS, not significant).

experiments were carried on. In Fig. 6b, over-expression of miR-223 obviously inhibited the expression of IL-1 $\beta$ compared with negative control group in vitro. Moreover, the expression of IL-1 $\beta$ was evidently higher in miR-223 inhibition group than control group (Fig. 6c). From 


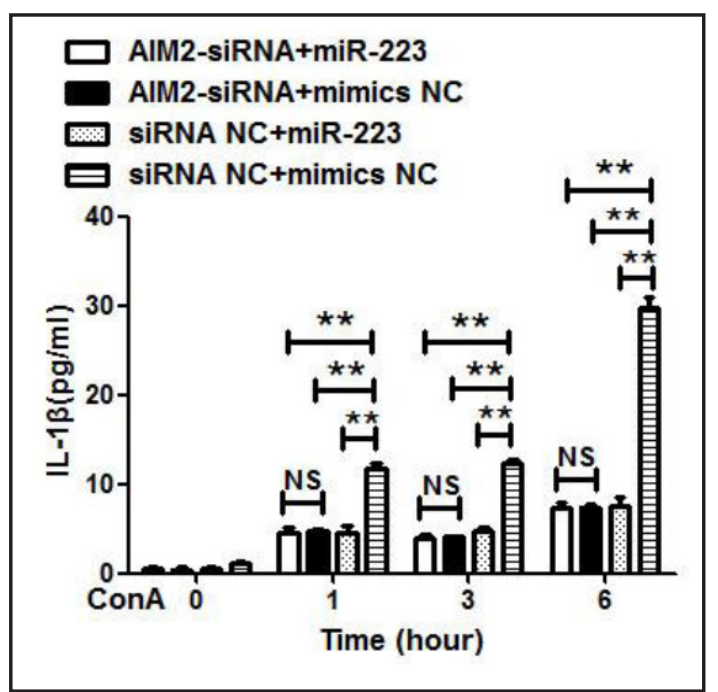

Fig. 8. Inhibition of MiR-223 to IL-1 $\beta$ production was depended on negatively regulating AIM2 in Kupffer cells treated with Con A. Primary cultured Kupffer cells were transfected with AIM2-siRNA or siRNA control. 12 hours later, cells were then transfected with miR-223 mimics or negative control. After 24 hours, cells were exposed to Con A $(5 \mu \mathrm{g} / \mathrm{ml})$ for $1 \mathrm{~h}$, $3 \mathrm{~h}$ and $6 \mathrm{~h}$, with siRNA NC+mimics NC $\mathrm{Oh}$ as control. Quantified protein level of IL-1 $\beta$ (ELISA), with siRNA $\mathrm{NC}+$ mimics $\mathrm{NC}$ 0h as control. Data from three independent experiments were shown as mean \pm SEM. (** $\mathrm{p}<0.01 ;{ }^{*} \mathrm{p}<0.05$; NS, not significant).

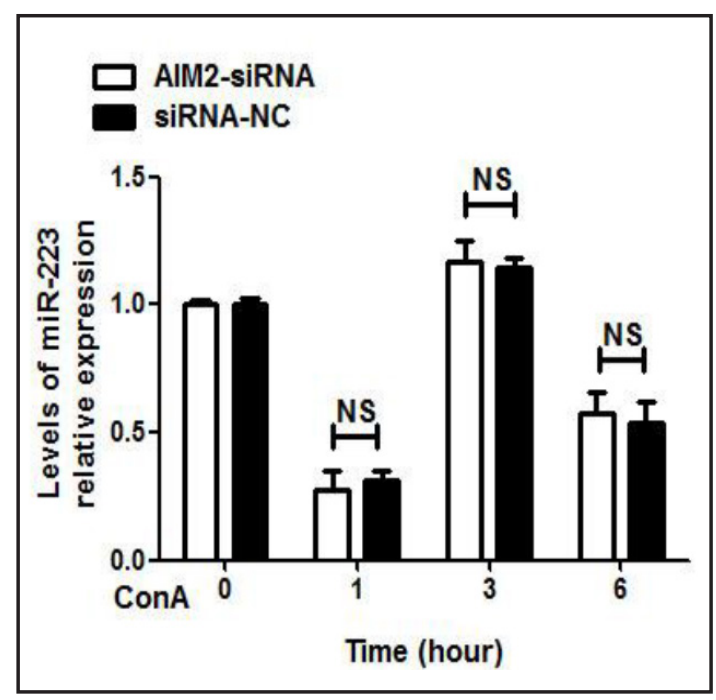

Fig. 9. AIM2 could not affect the expression of miR223 in Kupffer cells stimulated with Con A. Primary cultured Kupffer cells were transfected with AIM2siRNA or siRNA control. After 24 hours, cells were treated with Con A $(5 \mu \mathrm{g} / \mathrm{ml})$ for $1 \mathrm{~h}, 3 \mathrm{~h}$ and $6 \mathrm{~h}$. The expression of miR-223 was measured (qRT-PCR, normalized to U6), with siRNA-NC $0 \mathrm{~h}$ as control. Data from three independent experiments were shown as mean \pm SEM. $\left({ }^{* *} \mathrm{p}<0.01 ;{ }^{*} \mathrm{p}<0.05\right.$; NS, not significant).

the data, we proved that by inhibiting the production of IL-1 $\beta$, miR-223 could regulate the process of inflammatory response in Kupffer cells in the early stage of ALF.

MiR-223 down regulates the activation of AIM2 in Con A treated Kupffer cells

To explore the detailed mechanism of how miR-223 inhibited the IL-1 $\beta$ secretion, we investigated the relationship between miR-223 and AIM2 to find out whether miR-223 can regulate AIM2 in Kupffer cells in ALF. The experiment was carried out in vitro by transfecting miR-223 mimics and inhibitor. The result from Fig. 7a showed that the mRNA expression of AIM2 was suppressed by over expression of miR-223. An increase of AIM2 mRNA expression was observed when the expression of miR-223 was inhibited in Fig. 7b. The result of AIM2 protein level in Fig. 7c, 7d and 7e exhibited the similar phenomenon as the result of mRNA level. When miR-223 overexpressed, AIM2 protein expression level was lower than mimics NC transfected groups. However, when miR-223 suppressing occurred, comparing with Inhibitor NC transfected groups, AIM2 protein level appeared evidently higher. The scenario was proposed that miR-223 could inhibit the production of IL-1 $\beta$ by regulating AIM2 in Kupffer cells in Con A induced ALF.

MiR-223 can reduce the production of IL-1 $\beta$ by down-regulating the expression of AIM2 in Con A stimulated Kupffer cells

Further study to confirm the relationship between AIM2 and miR-223 was performed. First, AIM2-siRNA or relevant control was transfected into primary cultured Kupffer cells. After 24 hours, miR-223 mimics or negative control was also trnasfected into those treated cells. Cells were then treated with Con A $(5 \mu \mathrm{g} / \mathrm{ml})$ and subsequent experiment would carry on as mentioned in the previous step. The result in Fig. 8 showed that over expression of 


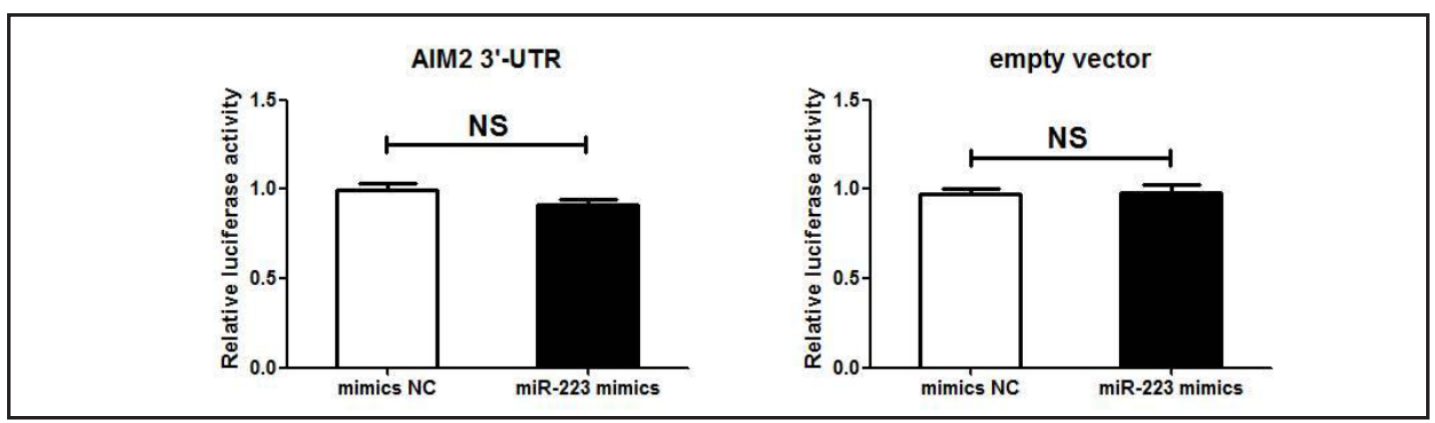

Fig. 10. AIM2 was not direct target of miR-223. RAW264.7 cells were co-transfected with AIM2 3'-UTR luciferase reporter plasmid or empty vector, and pRL-TK vector, together with miR-223 mimics or control. After $48 \mathrm{~h}$, firefly luciferase activities were measured (Dual-Glo Luciferase assay system, normalized to Renilla luciferase activity), with mimics $\mathrm{NC}$ as control. Data from three independent experiments were shown as mean \pm SEM. ${ }^{* *} \mathrm{p}<0.01 ;{ }^{*} \mathrm{p}<0.05 ; \mathrm{NS}$, not significant $)$.

miR-223 would lead to the decline of IL-1 $\beta$ secretion in siRNA control group. However, miR223 mimics did not contribute to the inhibition of IL-1 $\beta$ in AIM2-siRNA pretreated Kupffer cells. These results exhibited that the function of miR-223 to inhibit the expression of IL-1 $\beta$ was eliminated in AIM2-siRNA pretreated Kupffer cells. In brief, the conclusion was drawn that the influence of miR-223 regulation on IL-1 $\beta$ secretion was dependent on AIM2.

\section{AIM2 can not affect the activation of miR-223 in reverse}

In addition, we explored whether AIM2 could affect the expression of miR-223 in reverse. From Fig. 9, we found that compared with siRNA control group, expression of miR-223 kept stable when AIM2 was suppressed. Therefore, AIM2 might not influence the expression of miR-223 in reverse.

\section{AIM2 is not direct target of miR-223}

To further investigate relationship between AIM2 and miR-223, we explored whether AIM2 was direct target of miR-223. In Fig. 10, relative luciferase activities in miR-223 mimics transfected cells were not evidently different from they were in control group. The conclusion was drawn that AIM2 was not direct targeted by miR-223.

\section{Discussion}

Kupffer cells activation happened at the early stage of ALF and has been known as a crucial component in the initial part of pathogenesis of ALF [31]. Our previous report showed that expression changing curves of TNF- $\alpha$ and IL- 6 in early Con A induced ALF period, and also indicated the activation status of Kupffer cell was firstly pro-inflammatory, while the pro-inflammatory activity gradually decreased as the process went by. In other words, antiinflammatory activity of Kupffer cell augmented in the later stage [9]. Our present study confirmed that macrophages switched from pro- to anti-inflammatory in the early phase of ALF, by exploring relative expression level of Arg 1(M2 markers) in isolated Kupffer cells. As a classic M2-type macrophage marking molecule, change in Arg1 expression level represents change in M2-type macrophage quantity [25, 32]. Meanwhile, change in M2-type cell quantity could reflect shift in M1-M2 equilibrium. Different from M1-type, M2-type functioned antiinflammatorily. Shift in M1-M2 equilibrium could also reflect cell inflammatory status. 1 hour after Con A inducing, Kupffer cells were activated, and mouse cells appeared proinflammatory. Factor TNF- $\alpha$ and IL-6 expression level kept climbing [9]. M1-M2 equilibrium shifted towards M1 direction. Thus, Arg1 expression level stayed low. 3 hours after inducing, anti-inflammatory responses started and the equilibrium favored M2-type. At that point, 
Arg1 expression increased. However, as time passed by, the anti-inflammatory responses didn't last long. After 6 hours from inducing, Confluent necrotic foci were evidently observed and serum ALT and AST level evidently increased. At that point, Kupffer cells were mostly in the M1 type and pro-inflammatory responses dominated. Arg1 expression and M2-type quantity highly decreased. The change of crucial pro-inflammatory cytokine IL-1 $\beta$ was indicated in present study. 1 hour after Con A injection, Kupffer cells were activated and mainly turned into M1-type. Pro-inflammatory responses occurred, and pro-inflammatory factors were secreted. At this point, IL-1 $\beta$ expression level highly increased from normal status. 3 hours after inducing, anti-inflammatory responses were enhanced and Kupffer cells were mainly activated into M2-type. The M1-M2 equilibrium shifted, and number of M1type cells decreased. At this point, IL- $1 \beta$ expression level largely decreased comparing with its $1 \mathrm{~h}$ status. After 6 hours, although total number of Kupffer cells decreased, the remaining cells were giving intense pro-inflammatory responses, resulting in high IL-1 $\beta$ expression level. The experimental observation showed that the severity of pro-inflammatory activity of Kupffer cells in the later stage of ALF might result from mass production of IL-1 $\beta$. The scenario was proposed that the pro-inflammatory activity of Kupffer cells was gradually inclining during the process of ALF. Although the protective functions took place in about $3 \mathrm{~h}$ time, the suprressing effect was surpassed shortly afterwards. Furthermore, the proinflammatory properties in the later stage seemed to be more intense compared with early stage. Other research suggested that IL-1 $\beta$, mainly secreted from Kupffer cells in the liver, might induce the activation of inflammatory signaling pathway in hepatocytes and also influence normal hepatocellular physiological function such as declined production of hepatic glucose in liver diseases [10,32]. Moreover, the confluent necrotic foci were obvious at $6 \mathrm{~h}$ but not $3 \mathrm{~h}$ after exposure to Con A in present histological analysis. Serum ALT and AST level also increased significantly at $6 \mathrm{~h}$. Therefore, it seemed that the high level of IL-1 $\beta$ produced from activated Kuppfer cells might result in intense pro-inflammatory response in Kupffer cells that lead to hepatocytes injury.

Many papers provided the evidence that inflammasomes could play as a regulator in the process of liver injury induced by various stimuli like alcohol and LPS [33-34]. The regulation of inflammasomes in macrophage was thought as a necessary pathway to affect the normal physiological functions of hepatocytes in many liver diseases [14]. Deeper investigation showed that the inflammasome NLRP3 could modulate the macrophage polarization by regulating the release of IL-1 $\beta$. It was also found that the inflammasome NLRP3 could induce the pro-inflammatory response in macrophage [35]. AIM2, another typical inflammasome, could bind double strand DNA to contribute to pathogenesis of inflammation and it was also crucial to inflammatory respond in innate immunity system via different pathways from that of NLRP3 in liver disease [14, 29, 36]. Our observation showed that when up-regulation of AIM2 occurred, Kupffer cells exhibited as pro- inflammatory phenotype. Moreover, antiinflammatory status of Kupffer cells maintained when AIM2 was suppressed. We proposed the scenario that AIM2 could also be involved in the regulation of macrophage functional pattern, same as NLRP3. Further mechanism would be explored in present study. Previous report supported that the pathway of IL-1 $\beta$ production was related to the inflammasomes activation in macrophages [37]. Present observation in vivo showed that when inhibition of AIM2 occurred at $3 \mathrm{~h}$, the expression of IL- $1 \beta$ was reduced. We also confirmed that IL- $1 \beta$ would be effectively inhibited by blocking the expression of AIM2 after Con A stimulation in vitro. Taking together, these results could demonstrate that AIM2 might influence different patterns of Kupffer cells' activation by regulating the production of IL-1 $\beta$ in Con A induced ALF.

Previous study showed that microRNA was known as an important component of immune cell differentiation [38]. Some of them, such as miR-124 and miR-223, were recently studied for their important regulation in macrophage activation in inflammation $[22,24]$. Later paper supported that miR-223 was a novel regulator for macrophage polarization in obesity-associated adipose tissue inflammation. It was found that macrophages enhanced M1 while reduced M2 responses due to the deficiency of miR-223 [25]. In the present study, 
we observed that the expression of miR-223 decreased significantly at the initial phase after Con A stimulation. Afterwards, the expression started to increased, but declined again after reaching the peak at about $3 \mathrm{~h}$. Final expression level at $6 \mathrm{~h}$ is similar as the initial state. This result confirmed that declined expression of miR-223 might contribute to pro-inflammatory activation of Kuppfer cells. The detailed information of modulating by miR-223 was further investigated. Earlier reports showed that miR-223 down-regulation might enhance the production of IL-1 $\beta$ and IL-6 [26]. It was found in our observation that the production of IL-1 $\beta$ was evidently reduced by over expression of miR-223 in vitro, while the result were opposite when inhibition of miR-223 applied. These results might indicate that miR-223 could lead to anti-inflammatory activation of Kupffer cells by suppressing the production of IL-1 $\beta$ at $3 \mathrm{~h}$ after Con A treatment. However, the protective function failed again following with the significantly decrease of miR-223 at the later stage of ALF. In brief, miR-223 might modulate the immunological status of Kupffer cells by influencing the production of IL- $1 \beta$ in the early stage of Con A induced ALF. Deeper mechanism of how miR-223 regulated the secretion of IL-1 $\beta$ in ALF was still obscured. Previously, we showed that the inflammasome AIM2 could contribute to pro-inflammatory activation of Kupffer cells by enhancing the secretion of IL$1 \beta$ in Con A induced ALF. Two other groups had reported that certain inflammasome could be regulated by microRNAs. Their research indicates that miR-133a-1 and miR-146a could influence the expression of NLRP3 during infection [39, 40]. Later paper identified that miR-223 could regulate the inflammatory response by targeting inflammasome NLRP3 in macrophages. They clarified that the activity of NLRP3 is negatively correlated with miR223 expression [27]. Although the role of AIM2 was also crucial to inflammatory response in innate immunity system via different pathways from that of NLRP3 in liver disease[14], the details of AIM2 regulation were still undiscovered. Another important finding in present study was that miR-223 could down-regulate the expression of AIM2 in Kupffer cells in the early stage of Con A induced ALF. From our investigation, we found that over expression of miR-223 was accompanied by an obvious decrease in AIM2 expression of both RNA and protein level, on the contrary, increase of AIM2 was triggered by inhibition of miR-223 in vitro after stimulated with Con A. The scenario was brought out that by down-regulating the expression of AIM2, miR-223 could suppress the production of IL-1 $\beta$ in the early stage of ALF. Furthermore, we performed the transfection of miR-223 mimics to AIM2-siRNA pretreated cells. The result showed that miR-223 suppression effect on IL-1 $\beta$ production was depended on regulating AIM2. Therefore, we could conclude that miR-223 could lead to anti-inflammatory activation of Kupffer cells by suppressing the production of IL-1 $\beta$ via down-regulating AIM2. Our investigation in vitro also showed that over expression of miR-223 could effectively down regulate the expression of AIM2 and also suppress IL-1 $\beta$ production, even in the later stage of Con A stimulated ALF. However, in vivo, the expression level of miR-223 was evidently low at $6 \mathrm{~h}$ after Con A treatment, while expression level of ALT in serum highly increased compared with the control group. In brief, we found that miR-223 could effectively trigger the protective response to counteract serious damage result from pro-inflammatory response in Kupffer cells in the early stage of ALF. Zhuang's group also found that deficiency of miR-223 would lead to more severe adipose tissue inflammation [25]. Recent report showed that miR-223 might play an important role in HDL's antiinflammatory properties [41]. We also supported that the drastic declining of miR-223 at the later stage of ALF might be one of the most important reasons which contribute to the acute pro-inflammatory respond of Kupffer cells and ultimately lead to hepatocytes injury in the process of ALF. In addition, the possibility was explored that if change of inflammasome AIM2 might affect the expression of miR-223 in reverse. However, a negative answer was given from the observation. Moreover, the result of computational prediction via Targetscan (www.targetscan.org) showed that miR-223 could possibly target murine AIM2's 3'-UTR. However, the target site was poorly conserved. Dual Luciferase reporter system was used to verify if AIM2 was direct targeted by miR-223. However, no positive result was observed. Detailed relationship and mechanism between AIM2 and miR-223 in ALF would be identified in our future study. 
In summary, we concluded that miR-223 could lead to the change in activation pattern of Kupffer cells by affecting the production of IL-1 $\beta$ via AIM2 pathway in the early stage of Con A induced ALF. Future study of miR-223 might also provide a new train of thought for ALF early clinical treatment.

\section{Abbreviations}

ALT (alanine aminotransferase); ALF (acute liver failure); AIM2 (absent in melanoma 2); ANOVA (analysis of variance); Arg 1 (Arginase 1); Con A (Concanavalin A); DMEM (dulbecco's modified eagle medium); dsDNA (double strand DNA); ELISA (enzyme-linked immunosorbent assay); HBV (hepatitis B); IKK- $\alpha$ (IкB kinase $\alpha$ ); IL (interleukin); LPS (lipopolysaccharide); miR-223 (microRNA-223); M1 (classic activation); M2 (alternative activation); NF- $\mathrm{BB}$ (nuclear factor kappa light chain enhancer of activated B cells); NLRP3 (Nod-like receptor protein 3); RT-PCR (reverse transcription-polymerase chain reaction); SD (standard deviation); SDS-PAGE (sodium dodecylsulfate-polyacrylamide gel electrophoresis); siRNA (small interfering ribonucleicacid); TLR (Toll-like receptors); TNF- $\alpha$ (tumor necrosis factor-alpha).

\section{Acknowledgements}

This study was supported by the 12-5 State S\&T Projects of China (2012ZX10002007) and the National Basic Research Program (973 Program) (2007CB512905). We are grateful to Dr Qiao Yang (Shao Yifu Affiliated Hospital, School of Medicine, Zhejiang University) and Dr Yu Shi (First Affiliated Hospital, School of Medicine, Zhejiang University) for their technical assistance.

\section{Disclosure Statement}

The authors declare no commercial or financial conflict of interest.

\section{Reference}

1 Rolando N, Wade J, Davalos M, Wendon J, Philpott-Howard J, Williams, R: The systemic inflammatory response syndrome in acute liver failure. Hepatology 2000;32:734-739.

-2 Antoniades CG, Berry PA, Wendon JA, Vergani D: The importance of immune dysfunction in determining outcome in acute liver failure. J Hepatol 2008; 9:845-861.

- 3 Liu ZX, Govindarajan S, Kaplowitz N: Innate immune system plays a critical role in determining the progression and severity of acetaminophen hepatotoxicity. Gastroenterology 2004; 127:1760-1774.

-4 Malik R, Mookerjee RP, Jalan R: Infection and inflammation in liver failure: two sides of the same coin. J Hepatol 2009;51:426-429.

-5 Antoniades CG, Quaglia A, Taams LS, Mitry RR, Hussain M, Abeles R, Possamai LA, Bruce M, McPhail M, Starling C, Wagner B, Barnardo A, Pomplun S, Auzinger G, Bernal W, Heaton N, Vergani D, Thursz MR, Wendon J: Source and characterization of hepatic macrophages in acetaminophen-induced acute liver failure in humans. Hepatology 2012;56:735-746.

-6 Pradere JP, Kluwe J, De Minicis S, Jiao JJ, Gwak GY, Dapito DH, Jang MK, Guenther ND, Mederacke I, Friedman R, Dragomir AC, Aloman C, Schwabe RF: Hepatic macrophages but not dendritic cells contribute to liver fibrosis by promoting the survival of activated hepatic stellate cells in mice. Hepatology 2013;58:14611473. 
7 Leroux A, Ferrere G, Godie V, Cailleux F, Renoud ML, Gaudin F, Naveau S, Prevot S, Makhzami S, Perlemuter G, Cassard-Doulcier AM: Toxic lipids stored by Kupffer cells correlates with their pro-inflammatory phenotype at an early stage of steatohepatitis. J Hepatol 2012;57:141-149.

8 Murray PJ, Wynn TA: Protective and pathogenic functions of macrophage subsets. Nat Rev Immunol 2011;11:723-737.

-9 Yang Q Liu Y, Shi Y, Zheng M, He J, Chen Z: The role of intracellular high-mobility group box 1 in the early activation of Kupffer cells and the development of Con A-induced acute liver failure. Immunobiology 2013;218:1284-1292.

-10 Imamura M, Tsutsui H, Yasuda K, Uchiyama R, Yumikura-Futatsugi S, Mitani K, Hayashi S, Akira S, Taniguchi S, Van Rooijen N, Tschopp J, Yamamoto T, Fujimoto J, Nakanishi K: Contribution of TIR domain-containing adapter inducing IFN-beta-mediated IL-18 release to LPS-induced liver injury in mice. J Hepatol 2009; 51:333-341.

11 Dinarello CA: Interleukin-1 in the pathogenesis and treatment of inflammatory diseases. Blood 2011;117:3720-3732.

12 Martinon F, Burns K, Tschopp J: The inflammasome: a molecular platform triggering activation of inflammatory caspases and processing of prolL-beta. Mol Cell 2002;10:417-426.

13 Bauernfeind F, Ablasser A, Bartok E, Kim S, Schmid-Burgk J, Cavlar T, Hornung V: Inflammasomes: current understanding and open questions. Cell Mol Life Sci 2011;68:765-783.

14 Szabo G, Csak T: Inflammasomes in liver diseases. J Hepatol 2012;57:642-654.

15 Muruve DA, Petrilli V, Zaiss AK, White LR, Clark SA, Ross PJ, Parks RJ, Tschopp J: The inflammasome recognizes cytosolic microbial and host DNA and triggers an innate immune response. Nature 2008;452:103-107.

-16 Boaru SG, Borkham-Kamphorst E, Tihaa L, Haas U, Weiskirchen R: Expression analysis of inflammasomes in experimental models of inflammatory and fibrotic liver disease. J Inflamm (Lond) 2012;9:49.

17 Wu DL, Xu GH, Lu SM, Ma BL, Miao NZ, Liu XB, Cheng YP, Feng JH, Liu XB, Cheng YP, Feng JH, Liu ZG, Feng Ding, Na Liu, Li WQ, Zhao YR: Correlation of AIM2 expression in peripheral blood mononuclear cells from humans with acute and chronic hepatitis B. Hum Immunol 2013;74:514-521.

18 Chen K, Rajewsky N: The evolution of gene regulation by transcription factors and microRNAs. Nat Rev Genet 2007;8:93-103.

19 Bartel DP: MicroRNAs: genomics, biogenesis, mechanism, and function. Cell 2004;116:281-297.

20 O'Connell RM, Rao DS, Baltimore D: microRNA regulation of inflammatory responses. Annu Rev Immunol 2012;30:295-312.

21 Lopez-Ramirez MA, Wu D, Pryce G, Simpson JE, Reijerkerk A, King-Robson J, Kay O, de Vries HE, Hirst MC, Sharrack B, Baker D, Male DK, Michael GJ, Romero IA: MicroRNA-155 negatively affects blood-brain barrier function during neuroinflammation. FASEB J 2014;28:2551-2565.

22 Veremeyko T, Siddiqui S, Sotnikov I, Yung A, Ponomarev ED: IL-4/IL-13-dependent and independent expression of miR-124 and its contribution to M2 phenotype of monocytic cells in normal conditions and during allergic inflammation. PLoS One 2013;8:e81774.

23 Haneklaus M, Gerlic M, O'Neill LA, Masters SL: miR-223: infection, inflammation and cancer. J Intern Med 2013;274:215-226.

24 Li T, Morgan MJ, Choksi S, Zhang Y, Kim YS, Liu ZG: MicroRNAs modulate the noncanonical transcription factor NF-kappaB pathway by regulating expression of the kinase IKKalpha during macrophage differentiation. Nat Immunol 2010;11:799-805.

25 Zhuang G, Meng C, Guo X, Cheruku PS, Shi L, Xu H, Li H, Wang G, Evans AR, Safe S, Wu C, Zhou B: A novel regulator of macrophage activation: miR-223 in obesity-associated adipose tissue inflammation. Circulation 2012;125:2892-2903.

-26 Chen Q, Wang H, Liu Y, Song Y, Lai L, Han Q Cao X, Wang Q: Inducible microRNA-223 down-regulation promotes TLR-triggered IL-6 and IL-1 beta production in macrophages by targeting STAT3. PLoS One 2012; 7: e42971.

27 Bauernfeind F, Rieger A, Schildberg FA, Knolle PA, Schmid-Burgk JL, Hornung V: NLRP3 inflammasome activity is negatively controlled by miR-223. J Immunol 2012;189:4175-4181.

28 Chen F, Zhu HH, Zhou LF, Li J, Zhao LY, Wu SS, Wang J, Liu W, Chen Z: Genes related to the very early stage of ConA-induced fulminant hepatitis: a gene-chip-based study in a mouse model. BMC Genomics 2010;11:240. 
-29 Hornung V, Ablasser A, Charrel-Dennis M, Bauernfeind F, Horvath G, Caffrey DR, Latz E, Fitzgerald KA: AIM2 recognizes cytosolic dsDNA and forms a caspase-1-activating inflammasome with ASC. Nature 2009;458:514-518.

-30 Li L, Chen L, Hu L, Liu Y, Sun HY, Tang J, Hou YJ, Chang YX, Tu QQ Feng GS, Shen F, Wu MC, Wang HY: Nuclear factor high-mobility group box1 mediating the activation of Toll-like receptor 4 signaling in hepatocytes in the early stage of nonalcoholic fatty liver disease in mice. Hepatology 2011;54:1620-1630.

31 Yang Q Shi Y, He J, Chen Z: The evolving story of macrophages in acute liver failure. Immunol Lett 2012;147:1-9.

- 32 Yerkovich, ST, Rigby PJ, Fournier PA, Olynyk JK, Yeoh GC: Kupffer cell cytokines interleukin-1beta and interleukin-10 combine to inhibit phosphoenolpyruvate carboxykinase and gluconeogenesis in cultured hepatocytes. Int J Biochem Cell Biol 2004;36:1462-1472.

-33 DeSantis DA, Ko CW, Liu Y, Liu X, Hise AG, Nunez G, Croniger CM: Alcohol-induced liver injury is modulated by Nlrp3 and Nlrc4 inflammasomes in mice. Mediators Inflamm 2013;2013:751374.

34 Kim SJ, Lee SM: NLRP3 inflammasome activation in D-galactosamine and lipopolysaccharide-induced acute liver failure: role of heme oxygenase-1. Free Radic Biol Med 2013;65:997-1004.

-35 Pelegrin P, Surprenant A: Dynamics of macrophage polarization reveal new mechanism to inhibit IL-1beta release through pyrophosphates. EMBO J 2009;28:2114-2127.

-36 Fernandes-Alnemri T, Yu JW, Datta P, Wu J, Alnemri ES: AIM2 activates the inflammasome and cell death in response to cytoplasmic DNA. Nature 2009;458:509-513.

-37 Bergsbaken T, Fink SL, Cookson BT: Pyroptosis: host cell death and inflammation. Nat Rev Microbiol 2009; 7:99-109.

- 38 Baltimore D, Boldin MP, O'Connell RM, Rao DS, Taganov KD: MicroRNAs: new regulators of immune cell development and function. Nat Immunol 2008;9:839-845.

-39 Wang W, Stassen FR, Surcel HM, Ohman H, Tiitinen A, Paavonen J, de Vries HJ, Heijmans R, Pleijster J, Morre SA, Ouburg S: Analyses of polymorphisms in the inflammasome-associated NLRP3 and miRNA-146A genes in the susceptibility to and tubal pathology of Chlamydia trachomatis infection. Drugs Today (Barc) 2009;45:95-103.

40 Bandyopadhyay S, Lane T, Venugopal R, Parthasarathy PT, Cho Y, Galam L, Lockey R, Kolliputi N: MicroRNA133a-1 regulates inflammasome activation through uncoupling protein-2. Biochem Biophys Res Commun 2013;439:407-412.

41 Tabet F, Vickers KC, Cuesta Torres LF, Wiese CB, Shoucri BM, Lambert G, Catherinet C, Prado-Lourenco L, Levin MG, Thacker S, Sethupathy P, Barter PJ, Remaley AT, Rye KA: HDL-transferred microRNA-223 regulates ICAM-1 expression in endothelial cells. Nat Commun 2014;5:3292. 